\title{
Determinants to Tax Evasion Behavior in Vietnam
}

\author{
Thu Hang Nguyen ${ }^{1}$ \\ ${ }^{1}$ Ph.D. candidate, Law School, Shanghai University of Finance and Economics, Shanghai, China \\ Correspondence: Ph.D. candidate, Thu Hang Nguyen, Law School, Shanghai University of Finance and \\ Economics, Shanghai, China. E-mail: nthang011085@yahoo.com
}

$\begin{aligned} & \text { Received: November 4, } 2017 \\ & \text { Aoi:10.5539/jms.v7n4p123 }\end{aligned} \quad$ URL: http://doi.org/10.5539/jms.v7n4p123

\begin{abstract}
In Vietnam, tax evasion becomes a serious challenge facing tax administration and deterring tax revenue performance. The scarcity of evidence on determinants on tax evasion in Vietnam is a call for the author to design empirical study that will contribute to better understanding of the problem. This study examines determinants to tax evasion behavior in Vietnam, i.e. personal income tax case. Further, the study attempts to understand the underlying reasons for non-compliance decision. Data is gathered through survey questionnaire and interviews, and analyzed using SPSS software. Results suggest that government performance and tax knowledge are two real determinant factors to tax evasion in Vietnam.
\end{abstract}

Keywords: tax evasion, determinants to tax evasion

\section{Introduction}

There is no doubt that tax plays a very important role and matters the development of nations in the world (Miskama, Noorb, Omarc, \& AbdAzizd, 2013; Owens, \& Parry, 2009). It constitutes a very most important source of government revenue in countries in order to finance public services such as transportation, health care, education and others; however, many people do not understand the crucial role of tax towards the growth of the country. That's why, to all the countries, tax liability is compulsory to everyone, but many taxpayers have been intentionally and unintentionally finding ways to evade the tax law. Policy attention to tax evasion was spotlighted after the financial crisis of 2008, the Great Recession, and the large deficits that followed (Slemrod, 2016).

In Vietnam, as similarly as in some other developing countries, tax evasion is a serious challenge facing tax administration and deterring tax revenue performance. Despite the various tax reforms conducted by Vietnamese government to increase tax revenue over the years, prior statistical evidence has proven that the contribution of tax revenue to the government's total revenue remained consistently low. The ratio of tax revenue in the total State budget in Vietnam was $23.3 \%$ in period from 2011 to 2015, while those contributions in other neighboring countries such as Malaysia, Laos accounted for $24.3 \%$ and $23.4 \%$ respectively (Nhat Minh, 2016). Besides, from all the taxes, personal income tax has remained inefficient, unproductive and problematic in Vietnamese taxation system. Personal income taxes accounted for $24,5 \%$ of total tax revenue and $8,77 \%$ GDP on average across the OECD (Pomerleau, 2015; OECD, 2016). In Vietnam, this amount is smaller and on decreasing trend, at 5.5\% in 2014 due to tax evasion and ineffective tax policy (Ministry of Finance of Vietnam, 2015). While there are lots of efforts from the government and tax authorities to reform the tax system and policy in order to deter tax evasion, this situation seems to get worsen. Vietnam's economy is suffering fiscal deficit in the budget and the government spending is majorly financed by tax revenue. If tax evasion is addressed, fiscal deficit would be reduced. Personal income tax is playing an increasing role in government budget in Vietnam, even though it still represents a small portion of total tax revenue (Ngo, 2013). Increased utilization of personal income tax will cause the government to re-evaluate their policy with the emphasis on perceptions of tax evasion.

This is especially true for Vietnam where there is no empirical evidence on which to base policy design. Therefore, the scarcity of evidence on determinants on tax evasion in personal income tax in Vietnam is a call for the author to design empirical study that will contribute to better understanding of the problem of tax evasion in personal income tax. The study aims to finds out determinant factors to personal income tax evasion behavior in Vietnam. 


\section{The Theoretical Framework, Model and Methodology}

\subsection{Theoretical Framework}

According to Belkaoui (2004) and Khlif \& Achek (2015), the justifications for the determinants of tax evasion are based on three theoretical perspectives - general deterrence theory, economic deterrence models and fiscal psychology. Many empirical papers dealing with the determinants of tax evasion are identified (Ali, Fjeldstad, \& Sjursen, 2014; Belkaoui, 2004; Picur \& Belkaoui, 2006; Wright, 2010; Allingham, \& Sandmo, 1972). Based on theoretical underpinning and previous studies, determinant factors of tax evasion are classified into four groups as follows;

(1) Deterrence factors

(2) Government performance factor

(3) Policy fairness factor

(4) Knowledge factor

\subsubsection{Deterrence Factors (DEF)}

This group of factors based on the General Deterrence Theory (Khlif, \& Achek, 2015; Belkaoui, 2004). The theory refers to the capability of deterrence regulations (penalty and audit) to reduce the phenomenon of tax evasion and enhance tax compliance in one country.

There are many other empirical studies examining the relations of the deterrence factors to tax evasion. Allingham \& Sandmo (1972) conclude that there were positive relations between declared income and the penalty rate and the probability of detection (audit). It means that if the government increases the penalty and apply tougher audit, it will help to reduce tax evasion. Kiri (2016) reviews factors influencing on tax evasion. Based on previous researches' results, he comes to a conclusion that a high penalty rate tends to be an effective method to prevent people from evading tax, and that an increase in penalty rate enhances compliance behavior so decreases tax evasion actions. Similarly, Wright (2010) supposes general deterrence theory suggested that increasing the certainty of punishment, potential offenders may be deterred by the risk of suspicion. That is, deterrence factors are implemented by increasing the probability of detection (audit) and imposing of tougher penalties. Therefore, it comes to a hypothesis that applying deterrence methods by applying high penalty rate and tough audit regime would help to reduce tax evasion.

\subsubsection{Government Performance Factor (GPF)}

Government performance factors are based on the Theory of Fiscal Psychology and Economic Deterrence Theory (Khlif, \& Achek, 2015; Belkaoui, 2004; Damayanti, Sutrisno, Subekti, \& Baridwan, 2015).

The Fiscal Psychology Theory suggests the importance of positive policies that are developed by government to improve taxpayers' perception in government performance in order to reduce tax evasion (Damayanti, Sutrisno, Subekti, \& Baridwan, 2015). Moreover, Tsakumis et al. (2007) shows that trust in government performance is negatively associated with tax evasion across countries. Accordingly, as if the government performs better, the tax evasion behavior would be reduced.

Ali, Fjeldstad, \& Sjursen (2014) find out that tax compliance attitude was positively correlated with the provision of public services by the government. This expresses the role of government performance in providing public projects and services. Besides, The World Value Surveys project supports the efforts of governments to improve tax morale and tax compliance through strengthening and clarifying the links between revenue and expenditure, building taxpayer profiles, increasing the transparency of tax policy making and modernizing tax administration procedures to avoid negative interactions among the drivers of compliance (OECD, 2013). Gmb (2010) advises the governments to enhance tax compliance through a transparent, accountable and efficient manner by developing a sound state-society relationship and enhancing the legitimacy of the state taking into account the entire public system. Picur \& Belkaoui (2006) document that the low level of corruption is positively associated with tax compliance, whereas the high level of bureaucracy increases tax evasion. Economic Deterrence Theory basing on the cost and benefit analysis suggests tax evasion decreases if a taxpayer finds the benefit of the public expenditures for public projects and services as return for tax payments.

In Vietnam, the President Nguyen Xuan Phuc also agrees that the Vietnamese government should take the people's perception and satisfaction to assess the government performance and effectiveness (Hoai Thanh, 2017).

Based on theories and above empirical studies, another hypothesis would be that better government performance in taxpayers' perception would improve tax evasion behavior. Government performance in taxation issues can be 
shown in many aspects including in providing public projects and services, anti-corruption methods in taxation system, budget transparency and effectiveness, supporting service and guideline, policy reform.

\subsubsection{Policy Fairness Factor (POF)}

According to Price Waterhouse Cooper-PWC (n. d.), tax policy refers to what taxes governments choose to levy, in what amounts, and on whom. It concerns broad issues such as how much tax the government needs to collect in order to pay for expenditures and the effect that taxes can have on overall economic activity. It also concerns issues of fairness, by which who should pay taxes with how much in tax rates, and which allowances and incentives are allowed to narrow the gap of inequality.

Kircher, Hoelzl, \& Wahl (2008) suggest that the levels of tax compliance involved many contributing factors including the perceived of tax system fairness by taxpayers. Additionally, it's concluded that the high level of policy fairness is negatively associated with tax evasion (Richardson, 2006).

Many Vietnamese taxpayers suppose that they consider tax policy inequality regarding tax rate, tax allowance and tax incentives. Accordingly, the current tax policy in Vietnam is unfair because they are suffering a high tax rates for their income from salaries and wages. Besides, the current tax allowances are too low, so that they cannot afford their living expenses after paying tax and getting deduction from tax allowances. Moreover, there are no incentives for encouraging people to pay more taxes in comparison to those who don't pay taxes or pay lower tax amounts (Anh Hong, 2015; Le Thanh, 2017). As results, people perceive of better personal income tax policy fairness as if there are a lower tax rate, higher tax allowances, and more tax incentives.

\subsubsection{Knowledge Factor (KNF)}

Hassan et al. (2016) suppose that individual taxpayers need adequate various aspects of tax knowledge in order to fulfill their tax liability responsibly, precisely and timely. Without tax knowledge, they may involve in certain risks being penalized by the tax authority.

The Economic Deterrence Theory suggests the form of better education/knowledge to enhance tax compliance.

Findings from prior researches are mixed. Hassan et al. (2016) said that there are many cases of unintentional non-compliance in Malaysia due to taxpayers' limited knowledge about tax and poor familiarity with the new tax system. Ali, Fjeldstad, \& Sjursen (2014) come into a conclusion that tax knowledge and awareness are found to be positively correlated with tax compliance attitude. Kasipillai \& Jabbar (2003) and Kirchler et al. (2006) document that possessing tax knowledge would lead to higher compliance rates. On the contrary, Collins et al. (1992) find that the respondents' tax knowledge is not significantly correlated with their tax compliance behavior in general. An earlier study by Harris (1989) claim that tax knowledge has no direct significant impact on taxpayers' compliance behavior.

The study comes with a hypothesis that tax knowledge would lead to a positive impact on tax evasion behavior. Accordingly, people having better tax knowledge are likely to less evade taxes.

\subsection{Methodology}

The methodology applied in the paper is mixed method, which including in quantitative and qualitative approaches (Creswell, 2014). Quantitative approach is necessary because the study conducts an empirical study, collect data by survey questionnaire, and then then find out the determinants factors to tax evasion behavior in Vietnam. For this research, internet survey questionnaire is applied because it can be distributed easily and quickly, then help to save time and cost effectively, managed conveniently and the survey respondents can answer whenever they have free time (Sekaran \& Bougie, 2010).

Besides, the author designs open-ended questions to interview potential taxpayers to have further in-depth understanding on the underlying issues, so that qualitative method will support for the findings from the quantitative approach.

\subsubsection{Questionnaire}

\section{- Design the questionnaire}

Based on the theoretical framework, empirical studies, and reference to Vietnam personal tax law and regulations, interview information of taxpayers, the research questionnaires are designed as follows;

Using likert questions (Flatworldsolution, n.d), respondents are asked to evaluate people's knowledge and understanding on personal income tax in Vietnam, and people's perceptions on personal income tax related issues as well. 
The lilert scores range from 1 to 4 , which stand for the lowest level of "know nothing" of PIT related issues to the highest level of "know very well" of tax issues including tax law, tax calculation, tax forms declaration, online tax software, tax finalization and return, and penalty of tax evasion. This question is to measure the variable "tax knowledge factor"- KNF.

The study measures the deterrence factor (DEF), government performance factor (GPF) and policy fairness factor (POF) by likert questions to see people's perception of deterrence methods (high penalty, and tough audit and examination), government performance through tax reform, public projects and services, tax services, tax budget transparency, tax anti-corruption, and policy fairness in tax rates, tax allowances and tax incentives in Vietnam. The likert scores ranging from 1 to 4 point stand for four levels of agreement with the assessments, which include "Totally disagree", "Partially disagree", "Partially agree", and "Totally agree". Accordingly, higher scores mean a higher level perception of deterrence methods, government performance and policy fairness in Vietnam.

The question to clarify whether people evade tax or not is based specific actions in tax evasion regulations in Vietnam (i.e., Article 3, Circular no 166/2013/TT-BTC). As a result, people who perceive that they conducted one or more actions in the list mean that they evaded tax.

Besides, the questions on respondents' genders, ages, education levels, marriage status, employment, and living areas to figure out demographic characteristic of respondents are made.

The dependent and independent variables and observation are coded as follows (Table 1);

Table 1. Research variables and measurement items

\begin{tabular}{|c|c|c|}
\hline Code & Content of variable observations & Reference \\
\hline \multicolumn{3}{|c|}{ Deterrence factor (DEF) } \\
\hline DE1 & Penalty rates are high & \multirow{2}{*}{ General Deterrence Theory } \\
\hline DE2 & Audit regime and examination are tough & \\
\hline \multicolumn{3}{|c|}{ Government performance factor (GPF) } \\
\hline GP1 & More tax reform & \multirow{5}{*}{$\begin{array}{l}\text { Economic Deterrence Theory and } \\
\text { Fiscal Psychology }\end{array}$} \\
\hline GP2 & Clear tax guideline and supporting services & \\
\hline GP3 & Provide good public projects and services & \\
\hline GP5 & Transparent and effective tax budget expenditure & \\
\hline GP6 & Good methods for tax anti-corruption & \\
\hline \multicolumn{3}{|c|}{ Policy fairness factor (POF) } \\
\hline PO1 & Low tax rate & \multirow{3}{*}{$\begin{array}{l}\text { Fiscal Psychology; Anh Hong (2015); } \\
\text { Le Thanh (2017) }\end{array}$} \\
\hline $\mathrm{PO} 2$ & Suitable tax allowances & \\
\hline $\mathrm{PO} 3$ & Many tax incentives & \\
\hline \multicolumn{3}{|c|}{ Knowledge factor (KNF) } \\
\hline KN1 & Tax law & \multirow{6}{*}{$\begin{array}{l}\text { Ali, M., Fjeldstad, H.O., \& Sjursen, } \\
\text { I.H. (2014); Economic Deterrence } \\
\text { Theory }\end{array}$} \\
\hline KN2 & Tax calculation & \\
\hline KN3 & Declaration of tax forms & \\
\hline KN4 & Using online tax software & \\
\hline KN5 & Tax finalization and return & \\
\hline KN6 & Regulations of tax evasion & \\
\hline \multicolumn{3}{|c|}{ Tax evasion (TV) } \\
\hline TV1 & Delay submission of tax registration files/dossiers & \multirow{8}{*}{$\begin{array}{lll}\text { Ali, M., } & \text { Fjeldstad, H.O., \& } & \text { Sjursen } \\
\text { I.H., } & \text { (2014); } & \text { Circular } \\
\text { 166/2013/TT-BTC } & \end{array}$} \\
\hline TV2 & $\begin{array}{l}\text { Delay notification of information in registration dossiers compared with } \\
\text { required time }\end{array}$ & \\
\hline TV3 & Provide inappropriate information in tax declaration dossiers & \\
\hline TV4 & Delay submission of tax declaration dossiers compared required time & \\
\hline TV5 & $\begin{array}{l}\text { Declare wrong information leading to reduce tax amount or increase tax } \\
\text { amount refund }\end{array}$ & \\
\hline TV6 & Declare increase in tax costs or tax exempts/relief & \\
\hline TV7 & Failure to declare all taxable incomes & \\
\hline TV8 & Never conducted such above actions & \\
\hline
\end{tabular}

\section{- $\quad$ Testing and finalizing the questionnaire}

After the first drafting the questionnaire, the author ask for supervisor who always understand, give advices and support this study process, researchers who have much experiences in conduct survey questionnaire researches, tax experts who are also tax professors in Foreign Trade University, tax officers in Vietnam who understand well the regulations and the reality of law implementations to give comments on the survey design and contents. 
After receiving comments from supervisor and experts, some sentences in the questionnaire are reworded to make it become familiar with the life and less sensitive to answer. After that, the author conducts a test with potential respondents who are senior professors at university, accountant and audit consultant, and officers as well. They are randomly chosen by connecting and asking through zalo and email. The author finalizes the questionnaire after testing respondents.

\section{- Sampling and Data collection}

Survey sample is randomly selected. Responses taken from the sample will be either taken personally or through online platform of Surveymonkey.com. Accordingly, the author has launched the questionnaire on various channels such as social blogs, university alumni association, people community, friends and friends' relationship. As a result, the questionnaire is circulated around Vietnam in one month. The sample size gets 420 respondents. The data is processed by Statistical Package for Social Science (SPSS) software to get the results.

By information given from surveys, the author sorts and finds out most qualitative respondents and contact for further interviews to understand their in-depth opinions.

\subsubsection{Reliability of Survey}

The reliability of survey means that it's consistent and stable, and, hence, predictable and accurate (Kumar, 2005). That's the degree to which the questions used in a survey bring the same type information each time they are used under the same conditions.

The research variables are constructed from 2 to 6 different variables of observation; therefore, for reliability testing, the common methodological factors are the Cronbach Alpha coefficient (Suanders et al., 2007). To examine the relevance of an item of question, the total variable correlation coefficient (Hair et al., 2006) should be considered. Testing standards are Cronbach Alpha coefficients of at least 0.7 and a minimum total correlation coefficient of 0.3 (Nunally \& Burstein, 1994). Using SPSS software to process with the survey data, he Cronbach Alpha coefficient test shows that the coefficients are greater than 0.7 (Table 3). The correlation coefficients of the variables observed in a factor are greater than 0.3. This shows that research concepts are appropriate and reliable.

However, due to the limitation of time, the author fails to test the questionnaire with the same groups of respondents in many times to examine the consistence of answers. Besides, the paper is about "tax evasion" which is quite sensitive to answer. Then after getting comments from testing, the author has to reword some questions to get the information and respondents. Therefore, for some above aspects, the reliability is one of limitation of the study's methodology.

\subsection{Model and Hypothesis}

Based on the theoretical frameworks, the model and hypothesis of the study are described as follows;

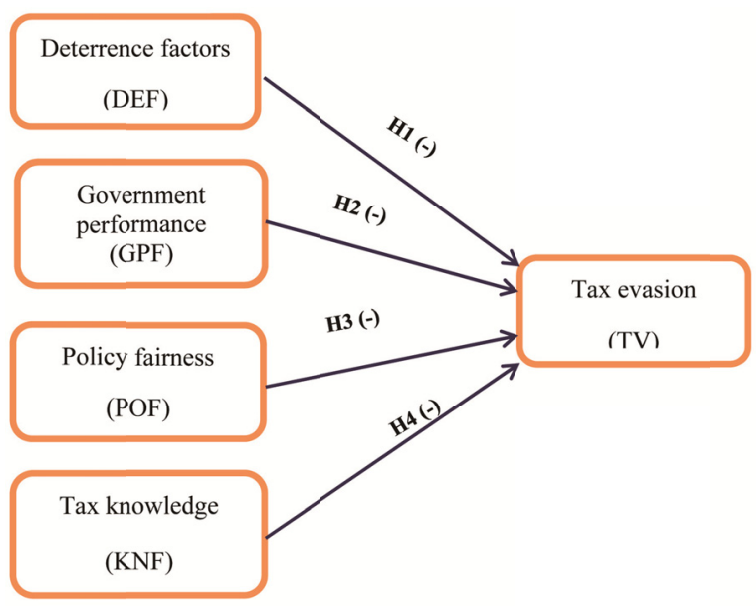

Figure 1. Model of the research

Source: The author develops the model based on General Deterrence Theory, Economic Deterrence models and Theory of Fiscal Psychology, and prior studies. 
The hypotheses of the research as follows;

Deterrence factor, government performance, policy fairness, and knowledge are negatively associated with tax evasion behavior.

H1: Deterrence factor (DEF) would reduce tax evasion behavior (-TV)

$\mathrm{H} 2$ : Better government performance (GPF) will reduce tax evasion behavior (-TV)

H3: Better policy fairness will reduce tax evasion behavior (-TV)

H4: Better knowledge in tax issues (KNF) would reduce tax evasion behavior (-TV)

\section{Results and Discussion}

\subsection{Respondents Profile}

A total of 420 questionnaires were gathered from the survey. As shown in Table 2, the majority of the respondents $(78 \%)$ are female, and $22 \%$ of respondents are male. The largest group (68\%), in terms of age, is those aged between 23 and 35. Specifically, (26\%) is aged between 35 and 55, while (5\%) is aged bellow 23, and $(2 \%)$ is aged above 55 . In terms of marital status, the majority of the respondents $(74 \%)$ are married, $(26 \%)$ are single. Regarding the level of study, the largest group (61\%) get university degree, (32\%) get master degree, $(6 \%)$ have Doctorate degree, and (1\%) graduate high school. In terms of employment, the majority of the respondents (39\%) work for private companies, $(31 \%)$ work for State enterprises, and $(24 \%)$ work for Foreign enterprises/organizations, $(5 \%)$ are freelance, and $(0.5 \%)$ are retired. As for living areas, respondents are majorly living in Northern cities and provinces (70\%), and (18\%) lives in the Southern and (12\%) is at the Central area.

Table 2. Respondents profile

\begin{tabular}{llll}
\hline Characteristics & Frequency & \% \\
\hline Age & Bellow 23 & 19 & $4.52 \%$ \\
& $23-35$ & 284 & $67.62 \%$ \\
& $35-55$ & 108 & $25.71 \%$ \\
\hline Gender & Above 55 & 9 & $2.14 \%$ \\
\hline Marital status & Male & 93 & $22.14 \%$ \\
& Female & 327 & $77.86 \%$ \\
\hline Education & Single & 108 & $25.71 \%$ \\
& Married & 312 & $74.29 \%$ \\
\hline Hivh school & 5 & $1.19 \%$ \\
& College & 1 & $0.24 \%$ \\
& University & 255 & $60.71 \%$ \\
& Master & 135 & $32.14 \%$ \\
& Ph.D. & 24 & $5.71 \%$ \\
\hline Employment & Northern & 296 & $70.48 \%$ \\
& Central & 50 & $11.90 \%$ \\
& Southern & 74 & $17.62 \%$ \\
\hline & State company & 131 & $31.19 \%$ \\
& Private company & 165 & $39.29 \%$ \\
& Foreign company & 100 & $23.81 \%$ \\
& Retired & 2 & $0.48 \%$ \\
& Freelance & 22 & $5.24 \%$ \\
\hline
\end{tabular}

Source: Descriptive frequency results by SPSS.

\subsection{Data Results and Discussion}

\subsubsection{Evaluation of Scale}

\subsubsection{Verification of Scale Reliability}

The research variables are constructed from 2 to 6 different variables of observation; therefore, for reliability testing, the common methodological factors are the Cronbach Alpha coefficient (Suanders et al., 2007). To examine the relevance of an item of question, the total variable correlation coefficient (Hair et al., 2006) should be considered. Testing standards are Cronbach Alpha coefficients of at least 0.7 and a minimum total correlation coefficient of 0.3 (Nunally \& Burstein, 1994). 
The Cronbach Alpha coefficient test shows that the coefficients are greater than 0.7 (Table 3). The correlation coefficients of the variables observed in a factor are greater than 0.3. This shows that research concepts are appropriate and reliable.

Table 3. Cronbach Alpha reliability test results

\begin{tabular}{lllll}
\hline No & Factor & Cronbach Alpha & Minimum of Total correlation & $\begin{array}{l}\text { Number } \\
\text { observation variables }\end{array}$ \\
\hline 1 & Deterrence factor & 0.818 & 0.693 & 2 \\
2 & Government performance & 0.904 & 0.713 & 6 \\
3 & Policy fairness & 0.775 & 0.462 & 3 \\
4 & Knowledge & 0.927 & 0.748 & 6 \\
\hline
\end{tabular}

Source: Results from data analysis using SPSS software version 20.0.

\subsubsection{Exploratory Factor Analysis (EFA)}

The Exploratory Factor Analysis (EFA) method is interdependence techniques, which means that there are no independent variables and dependent variables that rely on correlation between variables. EFA method is used to abbreviate a set $\mathrm{k}$ of observation variables into a set $\mathrm{F}(\mathrm{F}<\mathrm{k})$ of more meaningful factors. The basis of this reduction is based on the linear relationship of the elements to the original variables (observed variables). Mayers, L.S., Gamst, G., Guarino A.J. (2000) mentioned that in EFA, the method of extracting Pricipal Components Analysis with varimax rotation is the most commonly used method. According to Hair \& et al (1998), factor loading is the norm to ensure the true level of EFA, so that, the factor loading of greater 0.3 is considered to be the minimum. The condition for EFA is to satisfy the following requirements including in factor loading is greater $0.3(>0.3) ; 0.5 \leq \mathrm{KMO} \leq 1$. The KMO (Kaiser-Meyer-Olkin) coefficient is an index used to determine the suitability of factor analysis. High KMO values have factorial analysis as appropriate. Besides, Bartlett's test is statistically significant (Sig. $<0.05$ ), which is a statistical item used to consider the hypothesis of unrelated variables in the whole. If this test is statistically significant (Sig. $<0.05$ ), the observed variables are correlated in the overall. Moreover, percentage of explaining variance $(>50 \%)$, which represents the percent variance of the observed variables. If the variance is $100 \%$ then this value tells you how much factor analysis explains.

Table 4. Result of EFA of dependent variables

\begin{tabular}{|c|c|c|c|c|}
\hline \multirow[t]{2}{*}{ Observation variables } & \multicolumn{4}{|c|}{ Component } \\
\hline & 1 & 2 & 3 & 4 \\
\hline KN3 & .889 & & & \\
\hline KN5 & .886 & & & \\
\hline KN4 & .851 & & & \\
\hline KN1 & .848 & & & \\
\hline KN2 & .840 & & & \\
\hline KN6 & .827 & & & \\
\hline GP4 & & .881 & & \\
\hline GP3 & & .868 & & \\
\hline GP5 & & .843 & & \\
\hline GP2 & & .782 & & \\
\hline GP1 & & .705 & & \\
\hline DE1 & & & .895 & \\
\hline DE2 & & & .830 & \\
\hline PO3 & & & & .348 \\
\hline PO1 & & & & .903 \\
\hline $\mathrm{PO} 2$ & & & & .861 \\
\hline KMO & .849 & & & \\
\hline Sig. & .000 & & & \\
\hline Variance explanation (\%) & 75.27 & & & \\
\hline
\end{tabular}


The results of the analysis show that KMO coefficient is 0.849 that is greater than 0.5 , Bartlett's test has significant level which is less than 0.05 , the variance explained by $75.27 \%$ is greater than $50 \%$, loading factor coefficients are greater than 0.3 , and observation variables form four factors (Table 4) as same as four determinant factors developed by theoretical frameworks. This shows that the criteria of exploratory factor analysis are satisfactory, suggesting that the use of exploratory factorial analysis for research data is appropriate.

\subsubsection{Regression Results and Discussion}

With the factors formed in exploratory factor analysis, the author run a regression to find out which determinant factors that have a real impact on tax evasion behavior of Vietnamese taxpayers.

Table 5. Binary regression results

\begin{tabular}{llllllll}
\hline & & B & S.E. & Wald & df & Sig. & Exp(B) \\
\hline \multirow{4}{*}{ Step 1 $^{\text {a }}$} & DEF & .083 & .140 & .347 & 1 & .556 & 1.086 \\
& $\boldsymbol{G P F}$ & $\mathbf{- . 4 9 5}$ & $\mathbf{. 2 0 4}$ & $\mathbf{5 . 9 1 3}$ & $\mathbf{1}$ & $\mathbf{. 0 1 5}$ & $\mathbf{. 6 1 0}$ \\
& POF & -.045 & .163 & .075 & 1 & .784 & .956 \\
& $\boldsymbol{K N F}$ &. $\mathbf{4 4 6}$ & $\mathbf{. 1 5 5}$ & $\mathbf{8 . 2 3 3}$ & $\mathbf{1}$ & $\mathbf{. 0 0 4}$ & $\mathbf{1 . 5 6 2}$ \\
& Constant & -1.133 & .530 & 4.568 & 1 & .033 & .322 \\
\hline
\end{tabular}

Note. a. Variable(s) entered on step 1: DEF, GPF, POF, and KNF.

Source: Binary regression results using SPSS version 20.0.

The regression result shows that there are two independent variables including GDF and KNF in the models have significant values of less than 0.05 (Table 5). It means that there are only two determinant factors (GDF and $\mathrm{KNF}$ ) have real influence on tax evasion behavior in Vietnam at significance level of 5\%. Accordingly, government performance factor (GPF) is negatively associated with tax evasion behavior, while knowledge factor (KNF) is positively associated with tax evasion behavior. That means, better government performance will reduce tax evasion behavior ( $\mathrm{H} 2$ is supported); meanwhile, better knowledge on tax issues will increase tax evasion behavior (H4 is unsupported).

When it comes to government performance, taxpayers pay taxes in the pursuit of getting the benefits from tax budget expenditures for many fields which are implemented and managed by the government. Therefore, government performance is of importance to build up or damage people's trust in the government in order to decide whether paying taxes or evading taxes.

Further interviews show that many Vietnamese people don't know that the government publicizes the State budget's collection and expenditures on Statistics Yearbook annually, and for some others, they don't believe the transparency and the accuracy of the information on the report. Besides, their belief on the government was lost because there are lot of corruption cases and huge losses in State corporations. People call for the government to apply stronger methods for anti-corruptions to improve their trust into the government. Moreover, they also ask for further tax reform, improving tax services and public services and providing more public projects for taxpayers. As if the government improves its performance, taxpayers are encouraged to pay more taxes.

As far as taxpayers' knowledge on personal income tax issues is concerned. Many prior works concluded that better knowledge in tax would reduce tax evasion. However, it seems to be different in Vietnam's context. The regression result from survey data in Vietnam shows tax knowledge is a significant factor to determine tax evasion decision, and that better tax knowledge would increase tax evasion. Accordingly, in Vietnam, people who possess tax knowledge would try to find out ways to evade tax more and more, this may be due to the level of understanding of tax-related issues is not sufficient. To find out the underlying reason of the problem, we would look into description results of question regarding people's knowledge on personal income related matters such as personal income tax law, PIT calculation, PIT's forms declaration, using PIT declaration online software, and tax evasion. We could see that Vietnamese people's understanding about personal income tax related issues is quite modest and limited; especially they are lack of knowledge on regulations of tax evasion. They may even don't know they did evade tax.

\section{Conclusion}

The study contributes to literature on determinant factors to tax evasion and shows the practical implication for Vietnamese government and tax authority in designing the personal income tax policy in pursuit of addressing tax evasion situation. The regression results show that government performance and tax knowledge are determinant factors which have real impact on tax evasion behavior in Vietnam, while deterrence methods and policy fairness don't have any significant influence. Therefore, to improve tax evasion behavior in Vietnam, it's 
advisable for Vietnamese government to improve its performance and tax education system, rather than either imposing tougher sanctions or adjusting the tax rates and tax allowance deduction as well. The government performance in transparency and efficiency, public services, tax reform and services is a macro and complicated matter which needs further studies to address. As for tax knowledge, it's of importance because things seems different in Vietnamese context as if people possessing a better knowledge on tax issues tend to evade taxes more. It's noticeable and crucial for the tax authority and tax educators to change the strategy and the methods to educate tax issues and deliver tax knowledge to people, especially tax evasion related issues and regulations.

This paper is limited with Exploratory Factor Analysis (EFA), but Confirmatory Factor Analysis (CFA) technique would be used to verify the factor structure of a set of observed variables, and confirm the hypothesis that a relationship between the observed variables and their underlying latent construct exists.

\section{References}

Allingham, M. G., \& Sandmo, A. (1972). Income tax evasion: a theoretical analysis. Journal of Public Economics, 1, 323-338. https://doi.org/10.1016/0047-2727(72)90010-2

Ali, M., Fjeldstad, O. H., \& Sjursen, I. H. (2014). To Pay or Not to Pay? Citizens' Attitudes toward Taxation in Kenya, Tanzania, Uganda, and South Africa. World Development 64, 828-842. https://doi.org/10.1016/j.worlddev.2014.07.006

Alm, J. (2015). Understanding and Combatting Tax Evasion. Tulane Economics Working Paper Series, Working Paper 1508.

Alm, J. (2011). Measuring, explaining, and controlling tax evasion: lessons from theory, experiments, and field studies. International Tax Public Finance (2012), 19, 54-77. https://doi.org/10.1007/s10797-011-9171-2

Anh, H. (2016). Concerns with personal income tax: do not spend with the sick person. The Youth online journal. Retrieved from http://tuoitre.vn/tin/kinh-te/20161216/tang-xong-voi-thue-tncn-ban-can-nha-nop-thue-2-lan/1236922.html

Creswell, W. J. (2014). Research Design (4th edition). Thousand Oaks, California: SAGE Publications, Inc.

Flatworldsolution. (n. d.). What are different types of questionnaires? Retrieved from https://www.flatworldsolutions.com/research-analysis/articles/different-types-questionnaires.php

Gmb, H. (2010). Addressing tax evasion and tax avoidance in developing countries. Retrieved from https://www.taxcompact.net/documents/2011-09-09_GTZ_Addressing-tax-evasion-and-avoidance.pdf

Hoai, T. (2017). To assess the government performance and effectiveness through people's perception and satisfaction. Vietnamnet. Retrieved from $\mathrm{http} / / /$ vietnamnet.vn/vn/kinh-doanh/dau-tu/thu-tuong-nguyen-xuan-phuc-lay-su-hai-long-cua-nguoi-dan-la m-thuoc-do-cho-ket-qua-cong-viec-401346.html

Hasseldine, H. D., \& Bebbington, J. K. (1991). Blending economic deterrence and fiscalpsychology models in the design of responses to tax evasion: the New Zealand experience. Journal of Economic Psychology, 12(2), 299-324. https://doi.org/ 10.1.1.505.9669

Kumar, R. (2005). Research Methodology: A step-by-step guide for beginners (2nd edition, p. 132). Thousand Oaks, California: SAGE Publications.

McGee, R. W. (2006). Tax evasion and ethics: a demographic study of 33 countries. Workingpaper, Andreas School of Business, Barry University, Miami, FL.

Owens, J., \& Parry, R. (2009). Why tax matters for development. OECD Centre for Tax Policy and Administration. Retrieved from http://oecdobserver.org/news/archivestory.php/aid/2943/Why_tax_matters_for_development.html

Pomerleau, K. (2015). Sources of Government Revenue across the OECD 2015. Fiscal Fact No. 465, Apr.2015, Tax Foundation.

Wright, V. (2010). Evolution vs. Severity of Punishment. The Sentencing Project.

\section{Copyrights}

Copyright for this article is retained by the author(s), with first publication rights granted to the journal.

This is an open-access article distributed under the terms and conditions of the Creative Commons Attribution license (http://creativecommons.org/licenses/by/4.0/). 